\title{
Liquidity and Dividend Policy: International Evidence
}

\author{
Carroll Howard Griffin \\ College of Global Business and Professional Studies \\ Fontbonne University \\ 6800 Wydown Blvd, St. Louis MO 63105 USA \\ Tel: 210-569-9967Ｅ-mail: chgriffin@hotmail.com
}

\begin{abstract}
Since the days of Miller and Modigliani, academics have been studying dividend policy. There have been many theories as to why companies declare dividends, under what circumstances investors may prefer dividends to other forms of compensation, and factors that cause dividends to rise. However, the concept of liquidity has until very recently been largely ignored. This paper examines liquidity and dividend policy on the international level to determine what relationship the liquidity of a firm's stock has on the decision of how much dividend to disburse to investors. It finds that in several specific cases, there is an inverse relationship between stock liquidity and the dividend amount paid. This perhaps would point to dividends indeed at times compensating for lower stock liquidity.
\end{abstract}

Keywords: Liquidity, Dividend policy, International

JEL Classification: Market Efficiency

\section{Introduction}

Dividends, since the days of Miller and Modigliani, have been a topic of widespread research in academia and debate among practitioners. Dividends provide a "reward" in a sense to investors who have taken a risk by investing in the stock of a certain company. Income that is earned by the company is distributed to shareholders, and frequently increases over time. They are normally paid on a consistent basis, such as quarterly. Companies that have a record of paying dividends are usually traded at a premium versus those that do not. Investors in the company are thus provided cash flow without having to sell shares; therefore, traditionally, companies paying relatively high dividends have been purchased by those on a fixed income. Managers base current dividend levels on past dividend levels and current earnings and prefer dividends to be stable over time (Lintner, 1956).

Firms have several options when deciding what to do with net income. It can be distributed as dividends, but it also can be held as retained earnings or used to repurchase company equity shares in the secondary market. The company's decision of which option is preferable depends on several factors, one of which is the future prospects that the firm has. The common assumption is that if a company has many projects in mind for future growth, dividends will be held to a minimum or not paid at all. If the company does not have many projects in mind for the near future, the current revenue is more likely to be paid out to shareholders.

\subsection{Expectations}

Additionally, the expectation by investors of whether or not a firm will be paying dividends is of utmost importance. In other words, if a firm has a strong record of paying dividends (perhaps even increasing dividends over the years), then a sudden reversal of dividend policy will normally be detrimental to the stock price, at least in the short term (although theoretically, these funds would be reinvested in the form of retained earnings and ultimately lead to a higher share price). Thus, it is imperative that a firm give a clear indication of dividend policy and that dividends be predictable.

\section{Liquidity and dividends}

According to Miller and Modigliani, investors should be indifferent as to whether or not they receive dividends now or capital appreciation in the future, an idea known as the Dividend Irrelevance Theory. According to these authors, an increase in current dividends must lead to a reduction in the terminal value of the existing shares because the dividend stream on the existing shares must be diverted to attract outside capital from which higher future dividends are paid (1961). Although this theory is one of the most central theories of finance, their theory assumed that markets are frictionless and that there would be no direct or indirect costs of trading. The fact that trading friction is pervasive in financial markets leads one to believe that the more liquid a stock is the better and that investors do indeed have a dividend preference based on the liquidity of the stock (Banerjee et al, 2007). Stocks that pay dividends satisfy investors' need for liquidity. This is even more important for stocks that 
are thinly traded, for which investors may either have to wait a long time for a buyer and/or take a potentially lower price. Although the possibility of a link between liquidity and dividends dates back to Miller and Modigliani (1961), there is very little direct empirical evidence on the issue.

Liquidity is a relatively broad concept which in this case refers to the ability to trade large volumes quickly, at low cost, and without moving the price. Liquidity affects the attractiveness of a stock to investors. Investors may require higher expected returns on assets whose returns are sensitive to liquidity. Local market liquidity is also an important driver of returns in emerging markets (Bakaert et al, 2007). According to Graham et al, liquidity deteriorates before (after) anticipated (unanticipated) announcements (2006). This is applicable to emerging markets in the sense that emerging markets and economies are normally viewed as more volatile than that of the U.S. and other developed markets, with economics and/or political news leading to large swings in liquidity.

Publicly traded companies are not paying dividends as frequently as they did in the past, falling from $66.5 \%$ of firms in 1978 to $20.8 \%$ of firms in 1999 . This is attributable to several factors, such as a multitude of new listings, the increasing proportion of small firms with low profitability, and strong growth opportunities. However, dividend payers have a higher measured profitability and are larger than non-payers (Fama and French, 2001). According to Banerjee et al, firms with lower trading volume and a higher proportion of non-trading days (variables representing illiquidity) are more likely to pay dividends (and vice versa). The authors perform several tests, among which are share turnover to dividends and firm characteristics to dividends, with all of them seeming to confirm an inverse relationship between liquidity and the likelihood that dividends will be paid (2007). Additionally, an increase in liquidity effectively expands the set of positive Net Present Value projects a firm may undertake because it reduces the cost of capital (Becker-Blease et al, 2006). This would also tend to confirm an inverse relationship between liquidity and dividends because the more liquid a firm's stock, the more a company would be able to invest in positive NPV projects, thus decreasing the amount paid out in dividends.

\section{Liquidity and dividends in international firms}

The previously described studies all indicate that many firms are less likely overall to pay dividends now, especially if the stock is considered more liquid. Presently, however, the body of research on liquidity focuses on the United States, perhaps the most liquid market in the world. The U.S. market is not only much more prolific in number of traded securities, but also has an exceptionally diversified ownership structure. These characteristics are lacking in emerging markets, and may strengthen the liquidity effects (Bakaert et al, 2007). Additionally, according to Chuhan, lack of liquidity in international markets (especially emerging markets) is one of the main impediments to foreign investors' investing funds into these areas (1992). Additionally, in many emerging economies, the state has had a long history of involvement in corporate affairs, thus differentiating them even more from developed country based firms. Therefore, this study will take an international approach to liquidity, focusing on several international countries/regions to more closely ascertain the relationship between a firm's stock liquidity and dividend amounts paid. Given the differing levels of liquidity, history of government involvement and type of ownership structure between U.S. companies and international companies, as well as the dearth of research regarding liquidity on an international level, the research question is the following:

Given the differing company fundamentals, government involvement, and other macro and micro factors, what is the relationship between dividends and liquidity on an international level?

\subsection{Canada}

In Canada, agency problems seem to exist due to the relative scarcity of widely held corporations and the predominance of a family-controlled pyramid type structure. According to Attig, only $27.66 \%$ of Canadian firms are widely held, as compared to $40.26 \%$ of U.S. firms. Beyond this, he shows that multiple class shares and control pyramids are much more pronounced in Canada and that family management is present in approximately $70 \%$ of the analyzed firms. All of these factors are more apt to lead to asymmetric information, agency problems, and corporate diversions (2005). La Porta et al confirms that both large and small Canadian firms are less widely held, more family held, and more pyramidal than their U.S. counterparts (1999). According to Baker et al, there is a striking difference between ownership concentration between U.S. and Canadian firms in the sense that ownership of Canadian firms is highly concentrated and that a small group of large blockholders is the dominant form of ownership (2007).

According to Minh, the Toronto Stock Exchange (Canada's largest exchange) follows an upward trending intraday pattern, with volume low at the open, stable during the day and increasing at close (2007). The Canadian stock market, although relatively well developed when compared to other stock markets of the world, is much smaller than the NYSE or AMEX and thusly less liquid. However, as would be expected, Canadian 
dividend-paying firms are significantly larger and more profitable than non-dividend-paying firms, have greater cash reserves and fewer growth opportunities. (Baker et al, 2007).

\subsection{Latin America}

In general, liquidity in Latin America is very thin. There are only 7 listed firms per one million people in this region compared to 30 per one million in the U.S. Adding to the lack of liquidity is the fact that much of many companies' shares rests in the hands of a very concentrated group of shareholders or families. This generally leads to a misalignment of goals between the majority and minority shareholders (Santiago-Castro and Brown, 2007). Much of this can be traced back to the type of legal system Latin America initially adopted and has developed over the years. The Latin American legal system is based on French civil law, which traditionally has had weaker investor protection and less developed capital markets when compared to common law countries (La Porta et al, 1997).

For example, according to LaPorta et al, Mexican firms tend to be very family oriented, and thus very closely held (2000). Approximately 79\% of all companies in the country are classified as family-owned (Santiago-Castro and Brown, 2007). Brazil has a history of state intervention in economic affairs across many industries and many of these, such as telecommunications, mining and petroleum have received state incentives and subsidies over the years. Additionally, the state has worked in partnership with local business groups (all family owned and operated), thus creating a system whereby a privileged few have close connections to the state. Thus, the state has traditionally been the predominant ultimate owner, followed by families (with a dominant shareholder or group of shareholders) and multinational subsidiaries. In fact, approximately $43 \%$ of all businesses in the country are classified as family owned (Santiago-Castro and Brown, 2007). Although this very concentrated ownership structure has changed somewhat over the last decade or so, it still remains relatively quite concentrated (Rabelo and Vasconcelos, 2002). In Argentina, the Buenos Aires Stock Exchange was founded in 1854, with the Merval being the most important index (www.merval.sba.com.ar). Despite this long traditional of stock trading, company power tends to be concentrated in family and state hands (La Porta et al, 1999).

\subsection{Other country exchanges}

The Australian, British and Hong Kong markets are all very liquid. The ASX (Australia) exchange is one of the world's top ten listed exchange groups as measured by market capitalization (www.asx.com.au). The London Stock Exchange is one of the world's oldest and lists over 2800 companies with a market capitalization of over $£ 3.5$ trillion. It is considered Europe's most prestigious listing venue (www.londonstockexchange.com/en-gb/about). As of year end 2006, the Hong Kong Exchange boasted a market capitalization of over HK\$13 trillion, placing it $6^{\text {th }}$ among members of the World Federation of Exchanges. It also ranked $3^{\text {rd }}$ by total equity funds raised and $2^{\text {nd }}$ by new listings raised (Hong Kong Exchange Fact Book, 2006). According to LaPorta et al, large publicly traded firms tend to be very widely held in Australia and Britain, while highly family held in Hong Kong (1999). In fact, Hong Kong is not only characterized by concentrated family-shareholdings, but by low corporate transparency and no tax on dividends (Cheng et al, 2007).

\section{Methodology}

This paper seeks to determine the relationship between the liquidity of a firm's stock (as measured by Share Turnover) and the amount of dividends paid. It will examine the international markets of Canada (Toronto Stock Exchange), Australia (ASX), Mexico (Bolsa de Valores), Brazil (Bovespa), Argentina (Merval), Hong Kong (HKE) and the United Kingdom (FTSE 100). The variable of Share Turnover (shares traded/shares outstanding) will be used as the sole independent variable while Dividends per Share is the dependent variable. To begin, companies will be run according to the entire range of sample data, followed by sub-periods. The regression is then run again with companies sorted first by Market Capitalization and then by Earnings per Share to isolate any effect that these characteristics may have. The simple (linear) regression can be expressed in the following manner (with a negative relationship expected between the independent and dependent variables):

Div $=\alpha-\beta 1$ Turnover $+\varepsilon$

The time periods used are generally from 1988 to 2006, although in the case of Canada data from as far back as 1975 was used. Data was collected on a monthly basis from Compustat North America and Compustat Global. Sample sizes range from 21 firms (Argentina) to 249 firms (Canada), with an average being 92 for a given country. Variables have been selected based on Banerjee et al's study (with the exception of several variables which were not available). 
Liquidity is extremely difficult to measure. Although the availability of detailed microstructure data is widely available for the U.S., such data as absolute and proportional bid-ask spreads, quoted share and dollar depth are not available for many other markets, especially emerging markets (Bakaert et al, 2007). Therefore, a relatively general variable for liquidity (Share Turnover) is used in this study for which data is available for the countries in question. Despite its general nature, however, Share Turnover is commended for its empirical and theoretical proximity toward expressing liquidity (Banerjee et al, 2007).

The stock markets in these seven countries are relatively small and illiquid (some much more so than others). Also, differences in ownership structure and corporate governance as explained in the previous section could have an impact on liquidity and dividend strategy, thus making the international question an interesting one. Again, the purpose of this study is to obtain a preliminary view of the relationship between dividends and liquidity on an international level.

\section{Results}

The following are the results from the linear regression analyses. In Table 1, overall results are presented for each of the seven sample countries regarding Share Turnover. In Table 2, time has been divided into two subperiods to capture any effect that economic instability and market liberalization during the 1980s and 1990s may have caused, once again examining Share Turnover. Although several countries in Tables 1 and 2 showed statistically significant relationships between liquidity and dividends for either the overall time period or a subperiod, Mexico and Canada stand out as demonstrating the anticipated negative relationship.

\section{INSERT TABLE 1 HERE}

\section{INSERT TABLE 2 HERE}

In Table 3, the sample countries are classified according to Market Capitalization (a proxy for size). This is done to determine if the relationship of liquidity with dividends varies according to a firm's size. Brazilian and Canadian companies considered to have low Market Capitalization display a statistically significant inverse relationship, as do medium sized Canadian companies. It is noteworthy, therefore, that this statistically significant relationship between dividends paid and liquidity occurs most in smaller companies. This perhaps would support the idea that smaller companies feel the investors' need for liquidity more acutely than larger companies.

\section{INSERT TABLE 3 HERE}

In Table 4, sample countries are sorted according to Earnings per Share (a proxy for firm profitability). The only relationship of interest is the Low EPS Canadian firm grouping. This could perhaps support the above table as well and the idea that smaller/less profitable companies should perhaps be more aware to investors' liquidity requirements.

\section{INSERT TABLE 4 HERE}

Thus, taking the preceding tables together, it appears that there is a strong inverse relationship between share turnover and amount of dividends paid for several countries, most notably Mexico, Brazil and Canada (three countries in which liquidity has traditionally been somewhat lacking). Further research will need to be done to determine why exactly the relationship holds better in some countries than in others. However, if one were to look for a common thread, it would appear that stock markets that are more closely tied to those of the U.S. tend to exhibit a negative relationship between share liquidity and dividends paid to a greater degree than countries that have lesser ties with U.S. stock markets. Savvy investors from these countries may be willing to quickly abandon their own countries' stocks for those of the U.S. if not provided the desired liquidity.

\section{Conclusion}

Stocks that pay dividends satisfy investors' need for liquidity. This is even more important for stocks that are thinly traded, for which investors may either have to wait a long time for a buyer and/or take a potentially lower price. In the event that a stock is illiquid, a dividend provides an income stream that otherwise may be out of reach. For a liquid stock, on the other hand, an investor can create artificial dividends by selling a portion of the stock quickly, with fewer transaction costs, and possibly a higher price. In this study, the idea of an inverse relationship between dividends and stock liquidity on an international level has been examined. The international question is a valid one because liquidity is low compared with that of the U.S., especially in emerging markets. This study examined seven countries (a mix of developed and developing countries) and found that in several cases there exists an inverse relationship between stock liquidity and dividends paid, especially in smaller/less profitable firms. It also appears that countries whose stock markets have closer ties to the U.S. stock market may 
exhibit this relationship to a greater degree than those with lesser ties. More research will need to be done to determine if indeed this is the case. A policy implication for managers (both domestic and international) could include being aware of the particular company's size and profitability when setting dividend policy. If it is lower, it is perhaps wise to begin or continue to pay dividends. This perhaps would bolster investors' confidence in the company and create a tangible economic incentive for the investor to not abandon the stock.

\section{References}

Amihud, Y. \& Li, K. (2006). The declining information content of dividend announcements and the effects of institutional holdings. Journal of Financial and Quantitative Analysis, 41(3), 637-652.

Attig, N. (2005). Balance of power. Canadian Investment Review, 18(3), 6-12.

Australian Stock Exchange. (2008). About ASX. Overview and structure of ASX. [On-line] Available: http://www.asx.com.au/about/asx (September 15, 2008).

Baker, K., Saadi, S., Dutta, S. \& Gandhi, D. (2007). The perception of dividends by Canadian managers: new evidence. International Journal of Management Finance, 3(1), 70-81.

Bakaert, G., Harvey, C. \& Lundblad, C. (2007). Liquidity and expected returns: lessons from emerging markets. The Review of Financial Studies, 20(5), 1783-1797.

Banerjee, S., Gatchev, V. \& Spindt, P. (2007). Stock market liquidity and firm dividend policy. Journal of Financial and Quantitative Analysis, 42(2), 369-384.

Becker-Blease, J. \& Paul, D. (2006). Stock liquidity and investment opportunities: evidence from index additions. Financial Management, 35(3), 35-48.

Buenos Aires Stock Exchange. (2008), About the Buenos Aires Stock Exchange [On-line] Available: http://www.merval.sba.com.ar, (September 16, 2008).

Cheng, L., Fung, H. \& Leung, T. (2007). Information effects of dividends: evidence from the Hong Kong market. Review of Quantitative Finance and Accounting, 26(1), 32-48.

Chuhan, P. (1992). Are institutional investors an important source of portfolio investment in emerging markets? World Bank Policy Research Working Paper 1243. Washington D.C.: World Bank.

Docking, D. \& Koch, P. (2005). Sensitivity to investor reaction to market direction and volatility: dividend change announcements. The Journal of Financial Research, 28(1), 21-35.

Fama, E. \& French, K. (2001). Disappearing dividends: changing firm characteristics or lower propensity to pay? Journal of Financial Economics, 60, 3-30.

Graham, J., Koski, J. \& Loewenstein, U. (2006). Information flow and liquidity around anticipated and unanticipated dividend announcements. The Journal of Business, 79(5), 2301-2320.

Johnson, S., Lin, J. \& Song, K. (2006). Dividend policy, signaling, and discounts on closed-end funds. Journal of Financial Economics, 81(3), 539-553.

La Porta, R., Lopez-de-Silanes, F. \& Shleifer, A. (1999). Corporate ownership around the world. The Journal of Finance, 54(2), 471-496.

La Porta, R., Lopez-de-Silanes, F., Shleifer, A. \& Vishny, R. (1997). Legal determinants of external finance. The Journal of Finance, 52(3), 1131-1152.

Lintner, J. (1956). Distribution of incomes of corporations among dividends, retained earnings and taxes. American Economics Review, 46(2), 97-112.

London Stock Exchange. (2008). About the London Stock Exchange. [On-line] Available: http://www.londonstockexchange.com/en-gb/about (September 16, 2008)

Miller, M. \& Modigliani, F. (1961). Dividend policy, growth, and the valuation of shares. The Journal of Business, 34(4), 411-428.

Minh, V. (2007). Limit orders and the intraday behavior of market liquidity: evidence from the Toronto Stock Exchange. Global Finance Journal, 17(3), 379-396.

Pastor, L. \& Stambough, R. (2003). Liquidity risk and expected stock return. The Journal of Political Economy, 111(3), 642-659.

Rabelo, F. \& Vasconcelos, F. (2002). Corporate governance in Brazil. Journal of Business Ethics, 37(3), 378-392. 
Santiago-Castro, M. \& Brown, C. (2007). Ownership structure and minority rights: a Latin American view. Journal of Economics and Business, 59, 430-451.

Silva, F., Majluf, N. \& Paredes, R. (2006). Family ties, interlocking directors and performance of business groups in emerging countries: the case of Chile. Journal of Business Research, 59, 315-332.

Unknown. (2006). Hong Kong Exchange Fact Book.

Table- 1. Share Turnover (Full Time Period)

$* * *=$ significant at the $1 \%$ level

\begin{tabular}{|l|l|r|r|r|}
\hline Country & Year & \multicolumn{1}{|c|}{$\boldsymbol{\beta}$} & \multicolumn{1}{c|}{ t-stat } & \multicolumn{1}{c|}{ Sig. } \\
\hline Argentina & $1988-2006$ & 0.003 & 0.163 & 0.871 \\
\hline Australia & $1988-2006$ & 0.058 & 2.506 & $0.012^{* *}$ \\
\hline Brazil & $1990-2006$ & 0.003 & 0.392 & 0.695 \\
\hline Britain & $1988-2006$ & 0.037 & 5.147 & $0.000^{* * *}$ \\
\hline Canada & $1975-2006$ & -0.011 & -0.703 & 0.482 \\
\hline HK & $1988-2006$ & 0.000 & 0.008 & 0.994 \\
\hline Mexico & $1988-2006$ & -0.021 & -1.730 & $0.084^{*}$ \\
\hline
\end{tabular}

$* *=$ significant at the $5 \%$ level

$*$ significant at the $10 \%$ level

Table- 2.Share Turnover (Subperiod Results)

\begin{tabular}{|l|l|r|r|r|}
\hline Country & Year & \multicolumn{1}{c|}{$\boldsymbol{\beta}$} & \multicolumn{1}{c|}{ t-stat } & \multicolumn{1}{c|}{ Sig. } \\
\hline Argentina & $1988-1997$ & -0.010 & -0.388 & 0.698 \\
\hline & $1998-2006$ & -0.002 & -0.072 & 0.943 \\
\hline Australia & $1988-1997$ & 0.023 & 0.845 & 0.398 \\
\hline & $1998-2006$ & 0.118 & 3.845 & $0.000^{* * *}$ \\
\hline Brazil & $1990-1998$ & 0.016 & 1.329 & 0.164 \\
\hline & $1999-2006$ & -0.005 & -0.539 & 0.590 \\
\hline Britain & $1988-1997$ & 0.068 & 6.186 & $0.000^{* * *}$ \\
\hline & $1998-2006$ & -0.002 & -0.154 & 0.878 \\
\hline Canada & $1975-1990$ & -0.066 & -1.775 & $0.076^{*}$ \\
\hline & $1991-2006$ & -0.014 & -0.778 & 0.437 \\
\hline HK & $1988-1997$ & -0.009 & -0.575 & 0.565 \\
\hline & $1998-2006$ & 0.000 & 0.008 & 0.994 \\
\hline Mexico & $1988-1997$ & -0.040 & -1.906 & $0.057^{*}$ \\
\hline & $1998-2006$ & -0.012 & -0.767 & 0.443 \\
\hline
\end{tabular}

$* * *=$ significant at the $1 \%$ level

$*=$ significant at the $10 \%$ level 
Table- 3. Share Turnover (Classified by Market Capitalization)

\begin{tabular}{|c|c|c|c|c|}
\hline Country & $\begin{array}{l}\text { Market } \\
\text { Cap }\end{array}$ & $\boldsymbol{\beta}$ & t-stat & Sig. \\
\hline \multirow[t]{3}{*}{ Argentina } & High & -0.017 & -0.437 & 0.662 \\
\hline & Med & 0.011 & 0.124 & 0.901 \\
\hline & Low & -0.005 & -0.129 & 0.898 \\
\hline \multirow[t]{3}{*}{ Australia } & High & 0.012 & 0.465 & 0.642 \\
\hline & Med & -0.020 & -0.505 & 0.614 \\
\hline & Low & -0.086 & -1.407 & 0.159 \\
\hline \multirow[t]{3}{*}{ Brazil } & High & -0.001 & -0.101 & 0.920 \\
\hline & Med & 0.002 & 0.061 & 0.951 \\
\hline & Low & -0.225 & -9.656 & $0.000^{* * *}$ \\
\hline \multirow[t]{3}{*}{ Britain } & High & -0.003 & -0.213 & 0.831 \\
\hline & Med & 0.004 & 0.093 & 0.926 \\
\hline & Low & 0.077 & 3.850 & $0.000 * * *$ \\
\hline \multirow[t]{3}{*}{ Canada } & High & 0.049 & 1.337 & 0.181 \\
\hline & Med & -0.083 & -1.854 & $0.064 *$ \\
\hline & Low & -0.091 & -2.744 & $0.006^{* * *}$ \\
\hline \multirow[t]{3}{*}{$\mathrm{HK}$} & High & 0.028 & 1.043 & 0.297 \\
\hline & Med & 0.002 & 0.066 & 0.947 \\
\hline & Low & -0.001 & -0.056 & 0.956 \\
\hline \multirow[t]{3}{*}{ Mexico } & High & -0.026 & -1.242 & 0.214 \\
\hline & Med & -0.136 & -0.581 & 0.562 \\
\hline & Low & -0.003 & -0.131 & 0.896 \\
\hline
\end{tabular}

$* * *=$ significant at the $1 \%$ level

$*=$ significant at the $10 \%$ level

Table- 4. Share Turnover (Classified by Earnings per Share)

\begin{tabular}{|c|c|c|c|c|}
\hline Country & EPS & $\beta$ & t-stat & Sig. \\
\hline \multirow[t]{3}{*}{ Argentina } & High & -0.002 & -0.087 & 0.931 \\
\hline & Med & -0.009 & -0.262 & 0.793 \\
\hline & Low & -0.001 & -0.021 & 0.983 \\
\hline \multirow[t]{3}{*}{ Australia } & High & -0.015 & -0.698 & 0.485 \\
\hline & Med & -0.006 & -0.164 & 0.870 \\
\hline & Low & -0.141 & -0.878 & 0.380 \\
\hline \multirow[t]{3}{*}{ Brazil } & High & -0.001 & -0.113 & 0.910 \\
\hline & Med & -0.011 & -0.886 & 0.376 \\
\hline & Low & -0.001 & -0.042 & 0.967 \\
\hline \multirow[t]{3}{*}{ Britain } & High & 0.004 & 0.145 & 0.885 \\
\hline & Med & 0.002 & 0.160 & 0.873 \\
\hline & Low & 0.107 & 8.199 & $0.000 * * *$ \\
\hline \multirow[t]{3}{*}{ Canada } & High & 0.080 & 2.689 & $0.007 * * *$ \\
\hline & Med & 0.005 & 0.180 & 0.857 \\
\hline & Low & -0.090 & -3.529 & $0.000^{* * *}$ \\
\hline \multirow[t]{3}{*}{$\mathrm{HK}$} & High & -0.009 & -0.557 & 0.578 \\
\hline & Med & -0.014 & -0.658 & 0.510 \\
\hline & Low & 0.000 & -0.032 & 0.975 \\
\hline \multirow[t]{3}{*}{ Mexico } & High & -0.016 & -0.769 & 0.442 \\
\hline & Med & -0.025 & -1.058 & 0.290 \\
\hline & Low & -0.030 & -1.108 & 0.268 \\
\hline
\end{tabular}

$* * *=$ significant at the $1 \%$ level 